\title{
FOOD AVAILABILITY FOR INSECTIVORES IN GRASSLANDS - ARTHROPOD ABUNDANCE IN PASTURES, MEADOWS AND FALLOW LAND
}

\author{
ZAHN, A. ${ }^{1,2 *}$ - ENGLMAIER, I. ${ }^{3}$ - DROBNY, M. ${ }^{4}$ \\ ${ }^{1}$ Ludwig-Maximilians-Universität München, Department Biologie II \\ Großhaderner Str. 2, D-82152 Planegg - Martinsried, Germany \\ ${ }^{2}$ Bund Naturschutz, Kreisgruppe Mühldorf a. Inn \\ Pragerstraße 6, D-84478 Waldkraiburg, Germany \\ ${ }^{3}$ FAU/NA BÜRO, Murschall 5, D-84529 Tittmoning, Germany \\ ${ }^{4}$ Bund Naturschutz, Kreisgruppe Freising \\ Mjor-Braun-Weg 12, D-85354 Freising, Germany \\ *Corresponding author \\ e-mail: Andreas.Zahn@iiv.de \\ (Received $13^{\text {th }}$ February 2010 ; accepted $10^{\text {th }}$ March 2010)
}

\begin{abstract}
We studied arthropod occurrence in fallow land, extensively used pastures, extensively used meadows (cut twice or three times a year) and intensively used meadows (cut more than three times a year) in Upper Bavaria. Medium-sized arthropods $(5-15 \mathrm{~mm})$ were encountered much less frequently on intensively used and fallow land than on pastures and extensively used meadows. Large individuals $(>15 \mathrm{~mm})$ were observed most frequently on pastures but were hardly found on intensively used meadows. In autumn they occurred almost exclusively on pastures and fallow land. Species richness was the highest on pastures and the lowest on intensively used meadows. The study underscores the depletion of arthropod fauna and in particular the decline of large arthropods on intensively used meadows. It indicates that extensively used meadows and extensively used pastures in particular are the most favourable sources of nutrition for insectivores such as reptiles, amphibians, birds or bats.
\end{abstract}

Key words: land use, habitat management, grazing, species diversity, insects

\section{Introduction}

Grasslands are regarded as important foraging areas for many insectivores in Europe, such as birds (Vickery, 2001; Barnet et al., 2004), bats (Güttinger, 1997) or amphibians and reptiles (Langton and Burton 1997). Adequate grassland management is therefore an important tool for the conservation of arthropod eaters (Plantureux et al., 2005). The intensification of grassland usage is supposed to have a negative impact on arthropod diversity (McCracken and Tallowin, 2004). Intensively managed meadows and pastures usually harbour a depleted arthropod fauna (Kruess et al., 2002; Manhart et al., 2004). However, different aspects of grassland management are mainly discussed from the view of insect conservation (e.g. Carvell, 2002; Wetterstein and Schmid, 1999; Vulliamy, 2006; Sjödin, 2007; Radlmair and Dolek, 2002). Intensive application of fertilizers and frequent mowing or heavy grazing have indeed a negative impact on many arthropod species (von Nordheim, 1992; von Wingerden et al., 1992; Benton et al., 2003) and this may have consequences also for species depending on arthropods as food (Vickery, 2001).On the other hand, high biomasses of some arthropods and thus plenty of food may occur at certain times in intensively managed grasslands, because of 
the high levels of nutrients in such meadows and pastures (Lauenstein, 1986; Barnett et al., 2004; Atkinson et al., 2005; Plantureux et al., 2005).

In Central Europe extensively used grasslands have become rare. Concerning the food supply for insectivores foraging in open lands, advice for the management of "normal" grasslands on soils of moderate humidity and medium or high nutrient levels is therefore needed. However, the knowledge of the overall arthropod availability in such grasslands is scarce, since many studies about insect populations concentrate on extensive grasslands on poor, dry or wet soils and include only few species or systematic groups (Elligsen et al., 1997; Gibson et al., 1992; Hänsel and Plachter, 2004; Manhart et al., 2004; Kruess and Tscharntke, 2002a, b; Wingerden et al., 1992; Sjödin, 2007 a,b; Perner et al., 2005). Moreover, in temperate regions, data about the arthropod availability in spring and autumn are needed. Climatic conditions reduce the food for arthropod predators during these "critical times" (Zahn et al., 2007a), when body fat storages have to be accumulated (in autumn) or replenished (in spring).

In our study we investigated abundance and body size of arthropods in differently managed types of grasslands with no, moderate or intensive usage.

\section{Study areas}

The 5 study areas were located in Upper Bavaria between the valleys of the rivers Isar and Inn:

a) slopes of the Inn valley near Stampfl $\left(12^{\circ} 19^{\prime}, 48^{\circ} 10^{\prime}\right)$,

b) a cultivated and drained fen at the river Isen near Walkersaich $\left(12^{\circ} 18^{\prime} .48^{\circ} 16^{\prime}\right)$,

c) moist grasslands at the river Inn near Jettenbach $\left(12^{\circ} 22^{\prime}, 48^{\circ} 09^{\prime}\right)$,

d) a recultivated gravel pit near Heldenstein $\left(12^{\circ} 23^{\prime}, 48^{\circ} 14^{\prime}\right)$,

e) a cultivated and drained fen in the valley of the river Isar near Freising $\left(11^{\circ} 40\right.$, $\left.48^{\circ} 22^{\prime}\right)$.

At these areas we studied grasslands of the following types: fallow land (former usage as meadow or field), extensively used pastures (1.5 - 2.0 animal units/ha), extensively used meadows (cut twice or three times a year), intensively used meadows (cut 4-6 times a year). In each area we chose at least one of each type, except Heldenstein, where only extensively used pastures and intensively used meadow existed. In both Heldenstein and Stampfl, two additional pastures were included. Except Stampfl, where sheep were kept on the pastures, cattle grazed in the other areas. While in Jettenbach cattle stayed on the same parcel from April to November, rotation pastures existed at the other sites.

We excluded grasslands of high botanical value or of usages being unusual nowadays (e.g. cut only once per year) from the study. Additionally we excluded grasslands of very low productivity on very wet, dry or poor soils.

\section{Methods}

We took samples from May to October 2005 using a hand net (diameter 40cm, mesh $1 \mathrm{~mm})$ between 2 and $7 \mathrm{pm}$ when the weather was dry and warm $\left(>10^{\circ} \mathrm{C}\right)$. At each site we conducted 100 standardised beats with the net in a minimum distance of $5 \mathrm{~m}$ from shrubs and $1 \mathrm{~m}$ from the grassland edge. The arthropods were stored in a plastic bag and frozen until the analyses. At each site we noticed date, time, weather conditions, mean height of the vegetation and the number of flowering plants per $\mathrm{m}^{2}$ (classes: $1=0-5$

APPLIED ECOLOGY AND ENVIRONMENTAL RESEARCH 8(2): 87-100. http://www.ecology.uni-corvinus.hu • ISSN 15891623 (Print) • ISSN 17850037 (Online) (c) 2010, ALÖKI Kft., Budapest, Hungary 
inflorescences $/ \mathrm{m}^{2}, 2=5-15$ inflorescences $/ \mathrm{m}^{2}, 3=15-30$ inflorescences $/ \mathrm{m}^{2}, 4>30$ inflorescences $/ \mathrm{m}^{2}$ ). In August we determined the dominating plant species of the sites and estimated the number of plant species per $\mathrm{m}^{2}$ (classes: $1:<10$ species $/ \mathrm{m}^{2}, 2=10-15$ species $/ \mathrm{m}^{2}, 3=16-20$ species $/ \mathrm{m}^{2}, 4>20$ species $\left./ \mathrm{m}^{2}\right)$.

The arthropods were distinguished on the level of the following suborders or families: Acarina.

Apoidea, Araneae, Blattodea, Brachychera, Caelifera, Coleoptera, Dermaptera, Ensifera, Formicidae, Heteroptera, Homoptera, Ichneumonidae, Lepidoptera, Mecoptera, Nematocera, Planipennia, Symphyta, Vespoidea. Based on this level we calculated the diversity of each sample (Shannon - Weaver index). As an index of body size we took the body length (including the head). We distinguished between the size classes: $<5 \mathrm{~mm}, 5-15 \mathrm{~mm},>15 \mathrm{~mm}$. As a rough estimation of differences in the species numbers, we determined the minimum number of species that could be determined by visual inspection according to (Bährmann and Müller, 1995). Since the data were not normally distributed, we used nonparametric statistics. The Mann-Whitney-U-Test was used to test for differences between groups. Relations between independent variables were tested using Spearmans correlations coefficient and Kendall's Tau. If no other explanation is stated, we gave means and standard errors in the result section.

\section{Results}

\section{Phenology of arthropods}

Heteroptera, Ensifera, Caelifera and Coleoptera were the most abundant from June to August (Fig. 1a). Araneae, Hymenoptera (except ants) and Homoptera reached their maximum numbers in late summer and autumn. Diptera, which reached the highest numbers of individuals from all groups (Fig. $1 \mathrm{~b}$ ), were the most common in spring, whereby very small species $(<3 \mathrm{~mm})$ prevailed. Members of other groups occurred only sporadically in the samples. Acarina were found mainly in spring, Formicidae were more abundant in June, Lepidoptera, Planipennia and Mecoptera from June to August, Blattodea and Dermaptera from June to September. 

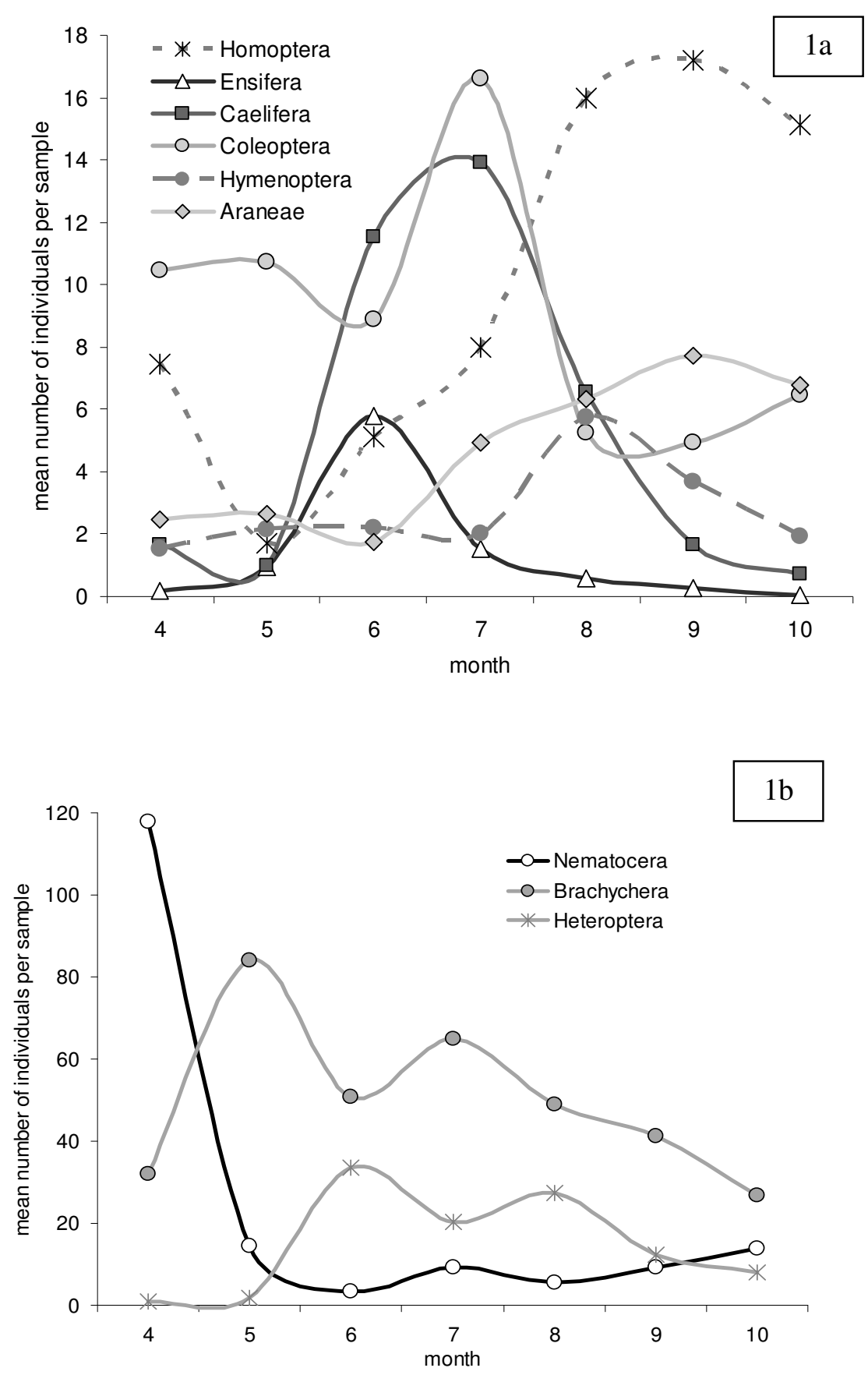

Figure 1. Phenology of regularly occurring Arthropods.

Given is the mean number in all samples $(n=15-19)$ per month $(a, b)$.

Heteroptera, Brachycera and Nematocera are presented separately because of their high numbers (b) 


\section{Effects of grassland management}

The arthropod fauna of the studied grassland habitats differed considerably (Fig. 2). Brachycera were the dominating group in meadows (both extensively and intensively used). In intensively used meadows, most samples consisted mainly of small flies $(<5 \mathrm{~mm})$. Besides these, only Nematocera, Heteroptera, Homoptera and Coleoptera occurred regularly in this grassland type.

Hymenoptera (except ants) and Homoptera reached the highest numbers in extensively used meadows. Caelifera, Coleoptera and Homoptera showed their maximum abundances in pastures, Araneae, Formicidae and Ensifera in fallow land. Mecoptera occurred only in pastures and extensively used meadows. In intensively used meadows they were missing, just like Demaptera and Planipennia.

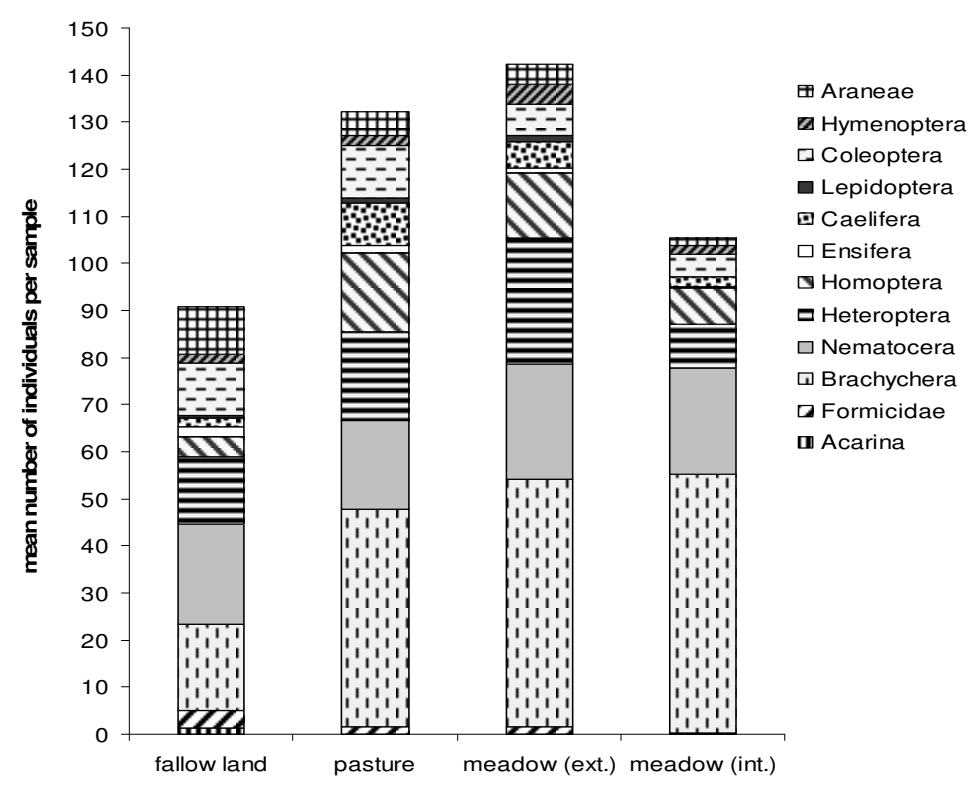

Figure 2. Frequency of different arthropods in samples taken in fallow land $(n=26)$, pastures $(n=60)$, extensive meadows $(n=26)$ und intensive meadows $(n=33)$

Large arthropods (> $15 \mathrm{~mm}$ ) were the most abundant in pastures and rare in intensively used meadows (Fig. 3), where even during summer (June - August) they occurred only in $30 \%$ of the samples! On the contrary, $80 \%$ of the samples taken in other types of grassland contained large individuals during these months. In autumn, large arthropods were regularly found only in pastures and fallow land: In September and October, they were proven in $75 \%$ of the pastures, $62 \%$ of fallow lands, $50 \%$ of the extensively used meadows and $30 \%$ of the intensively used meadows. While in intensively used meadows "large arthropods" consisted only of Caelifera and Nematocera, we found five groups of arthropods in fallow land, six in extensively used pastures and nine in meadows (Fig. 4).

Medium sized arthropods $(5-15 \mathrm{~mm})$ reached their lowest levels in fallow land and intensively used meadows. They reached their highest numbers in extensively used meadows from May to June (Fig. 3). Small arthropods $(<5 \mathrm{~mm})$ occurred mainly in spring and late summer, whereby Diptera prevailed. In this size class, the differences 
between grassland types were comparatively small. The lowest numbers were found in fallow land (Fig. 3).

In most months, the highest diversity (Shannon-Weaver index) was measured in fallow land (Fig. 5). Pastures came off second best. Intensively used meadows had the lowest values in summer, but the index was comparatively high in May and did not differ much from extensively used meadows in April, September and October. Over the whole season, the Shannon-Weaver index was the highest in fallow land $(1.75 \pm 0.01)$, slightly lower in pastures $(1.59 \pm 0.05)$, followed by extensively used meadows $(1.44 \pm$ $0.09)$. The lowest diversity occurred in intensively used meadows $(1.2 \pm 0.06)$.
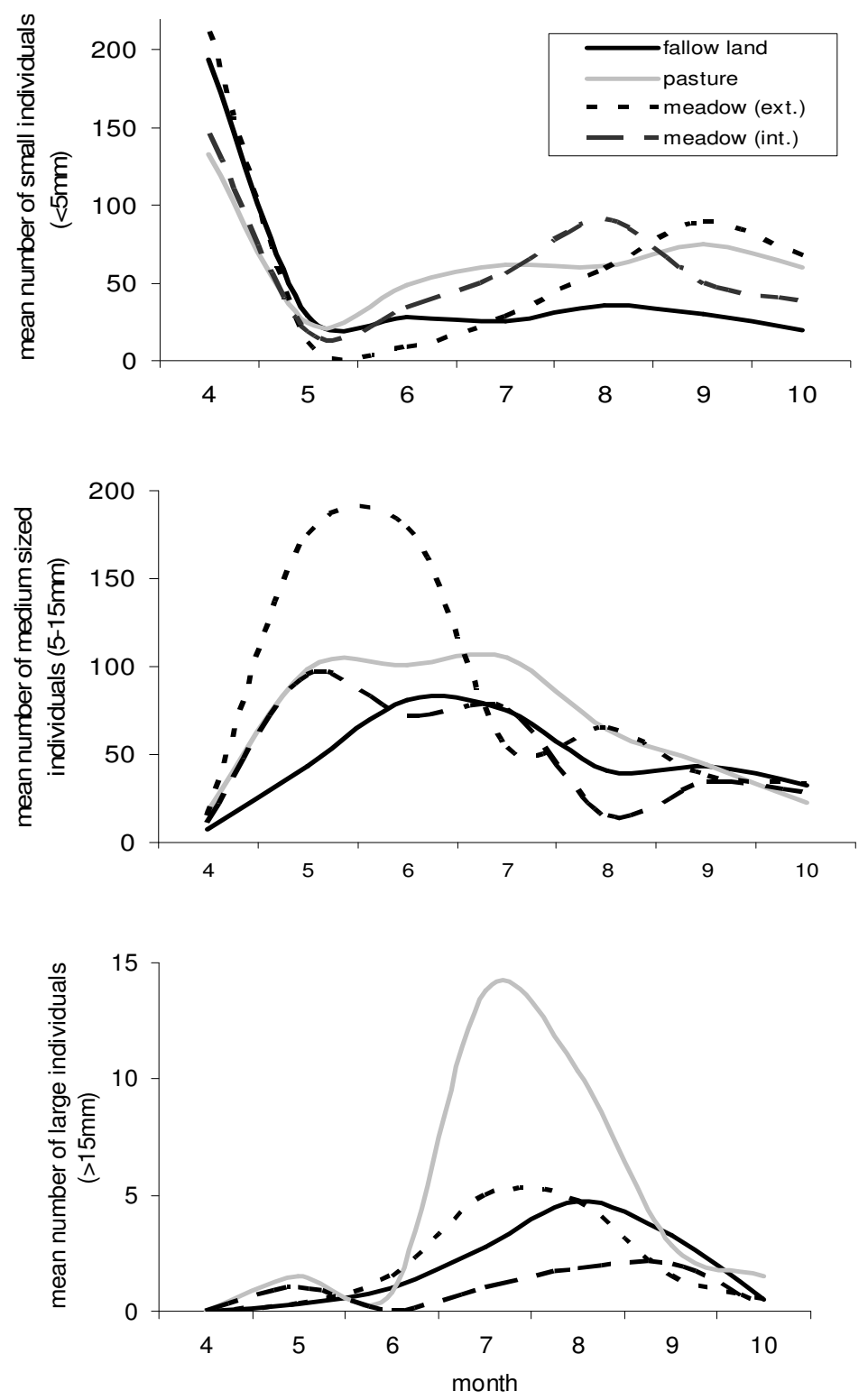

Figure 3. Frequency of small $(<5 \mathrm{~mm})$, medium sized $(5-15 \mathrm{~mm})$ and large $(>15 \mathrm{~mm})$ arthropods in different grasslands during the year (means). Fallow land $(n=26)$, pastures $(n=60)$, extensive meadows $(n=26)$ and intensive meadows $(n=33)$ 
However, in respect of the species richness (variable "minimum species number") the patterns were somewhat different. The most species per sample were found in pastures $(23.8 \pm 4.2)$, followed by extensively used meadows $(21.5 \pm 7.4)$. In fallow land, the habitat type with the highest diversity, the minimum species numbers were lower than in both extensively used grasslands $(20.5 \pm 4.1)$. In the intensively used meadows the value was by far the lowest $(13.6 \pm 2.3)$.

The difference between intensively used meadows and the other types of grassland was significant (Mann-Whitney-U-Test; $\mathrm{p}=0.002$ ).

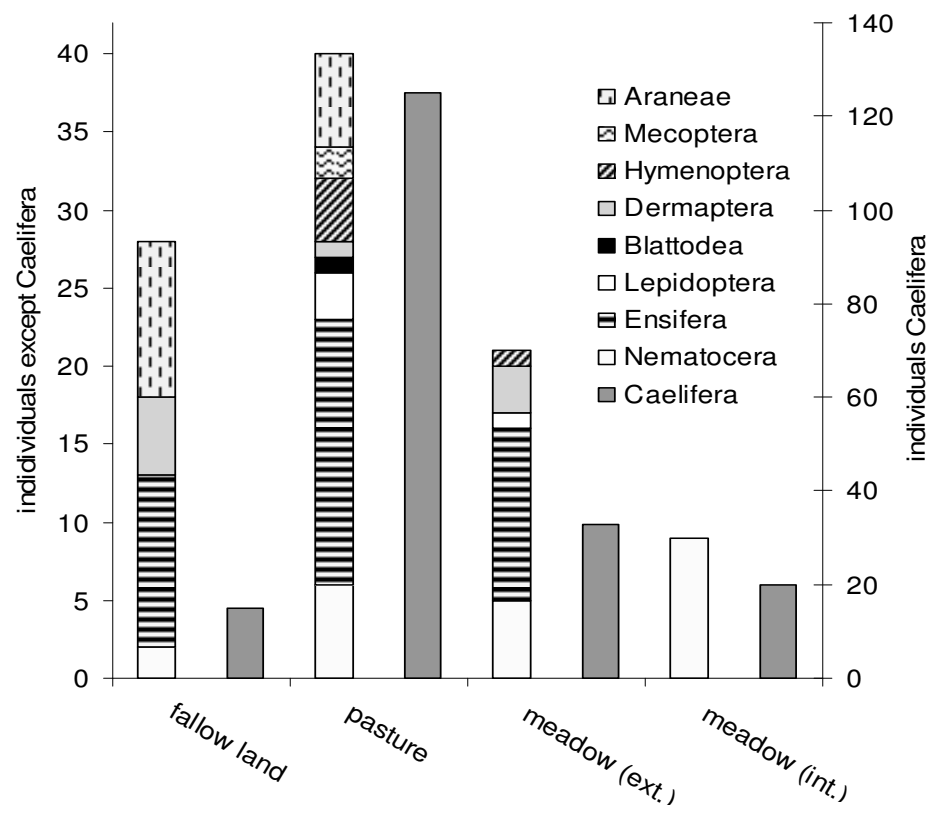

Figure 4. Composition of the group ,"large arthropods” (>15 mm). The number of Caelifera is given separately on the right ordinate

\section{Number of plant species, height of the vegetation and density of flowering plants}

Intensively used pastures were very poor in plant species. All sample sites belonged to the category $1\left(<10\right.$ species $\left./ \mathrm{m}^{2}\right)$. In pastures the highest numbers were reached (two sites belonged to the categories $2\left(10-15\right.$ species $\left./ \mathrm{m}^{2}\right)$, the other five to the category 3 (15-20 species $\left./ \mathrm{m}^{2}\right)$. In extensively used meadows the category 2 prevailed, only one site belonged to the category 3. Fallow land was poorer in plant species (classes 1 and 2 each at two sites).

The highest numbers of inflorescences in annual average were observed in extensively used meadows and pastures, the lowest numbers in intensively used meadows, where higher flower densities occurred only in short periods (e.g. when Taraxacum officinale was blooming in spring). Fallow lands differed to a large extent in flower densities. Some of them were poor in this respect throughout the whole season. It is worth mentioning that in all pastures and to a larger extent even in two extensively used meadows (before the last cut), considerable numbers of inflorescences were observed in autumn (September/October), when flowers were very rare at the other sites. 
We pooled all samples to analyse the influence of inflorescence density and vegetation height on the numbers of arthropods. Inflorescence density and vegetation height correlated $(\mathrm{r}=0.41, \mathrm{p}<0.01)$. If partial correlations were calculated, the inflorescence density had a stronger influence on the total individual number $(\mathrm{r}=0.33$, $\mathrm{p}<0.01)$ and the minimum species number $(\mathrm{r}=0.41, \mathrm{p}<0.01)$ than the height of the vegetation ( $\mathrm{r}=0.04$, ns. and $0.35, \mathrm{p}<0.01$, respectively). Consequently we used the inflorescence density to calculate correlations for the different arthropod groups. Except Nematocera in all groups the numbers of individuals positively correlated with the density of inflorescences. In Heteroptera $(\mathrm{r}=0.31)$, Caelifera $(\mathrm{r}=0.35)$, Ensifera $(\mathrm{r}=$ $0.39)$, Lepidoptera $(\mathrm{r}=0.39)$, Coleoptera $(\mathrm{r}=0.38)$ and Planipennia $(\mathrm{r}=0.27)$ the relation was significant ( $\mathrm{p}<0.05$, after Bonferroni-correction). Since not all of the groups use flowers directly as a resource, the density of inflorescences must be regarded as an indication of the undisturbed development of the vegetation, because flowers are greatly reduced by mowing, which also reduces the density of many arthropods.

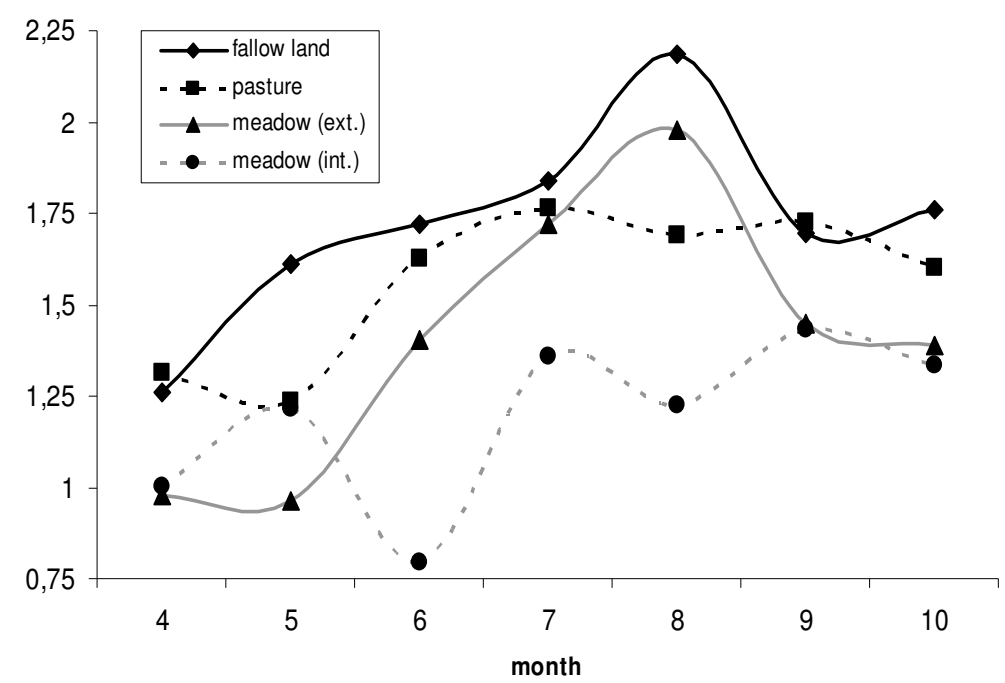

Figure 5. Diversity of species (Shannon-Weaver index) in the studied grasslands throughout the summer season

\section{Discussion}

\section{Intensively used meadows}

Intensively used meadows were characterised by low numbers of arthropod species, a low diversity of species and, in case of large arthropods, also by low numbers of individuals. While the low species numbers are probably caused by the reduced structural variation and the low diversity of the vegetation (Bornhold, 1991; Fricke and v. Nordheim, 1992), the number of individuals of many arthropod groups is greatly reduced after mowing (Manhart et al., 2004). The highest values in diversity and species richness in intensively used meadows is consequently reached in spring prior to the first cut. In early spring the fast vegetation growth in this type of grassland even favours the arthropod fauna compared to grasslands of lower productivity. 
Apart from mowing, the intensive application of fertilizers has a negative impact on some arthropod groups, e.g. on Caelifera (von Wingerden et al., 1992; Ingrisch and Köhler, 1998). Similarly Carabid beetles occur in intensively used meadows in reduced densities (Tietze, 1985; Blake et al., 1994). Not only the low abundance but also the low diversity of prey have a negative effect on the predators of arthropods: A higher species diversity results in a more even spatial and temporal distribution of food supply (Plantureux et al., 2005).

However, mass abundance of some arthropods (especially Diptera) occurs from time to time in intensively used meadows (Lauenstein, 1986). Such short term food opulence can be exploited by mobile and flexible predators. E.g. mouse-eared bats (Myotis myotis) hunt for crane flies (Tipulidea) when they are available in high numbers on freshly mown meadows during summer (Güttinger, 1997). On the contrary, many ground dwelling insectivores like amphibians, reptiles or shrews are not able to settle or forage regularly in intensively used meadows because of the low structural diversity and because of frequent machine processing (Blab, 1984; Langton and Burton, 1997). Overall, intensively used meadows turned out to be by far the most unfavourable type of grassland in respect of the food availability for insectivores.

\section{Fallow land}

Fallow lands were inhabited by much more arthropod species than intensively used meadows and resembled in this respect extensively used meadows and pastures. The diversity was even higher than in the other habitats, which corresponds to the findings of Kruess and Tscharntke (2002a,b). However, considering the numbers of medium sized and large arthropods, fallow land performed generally worse than extensively used meadows and pastures. In spring these arthropods were even rarer in fallow land than in intensively used meadows. A main reason might be the fact that the studied types of fallow land offer limited food for herbivore arthropods in this season, because the layer of leaf litter delays the growth of the vegetation. In autumn, on the contrary, fallow lands harboured the highest numbers of large arthropods apart from pastures. Fallow land provides good cover and a high structural diversity at that time, which favours large insects as Ensifera and spiders (Araneae), which are generally more common in fallow land than in pastures and meadows (Gibson et al., 1992). However, large differences exist between different types of fallow grassland: Older sites, characterised by low plant diversity and a dense layer of leaf litter, often show low species numbers in many groups of arthropods (e.g. Dewenter and Tscharntke, 2001), which can be enhanced by extensive types of usage (Zahn et al., 2007). In contrast, fallow grasslands on poorer soils may harbour rich arthropod communities (Balmer and Erhardt, 2000). In every case, the arthropods in fallow grasslands may be hard to exploit for insectivores, especially bats and many birds, which avoid foraging in dense high vegetation (Atkinson, 2005; Güttinger, 1997; Devereux et al., 2004).

\section{Extensively used meadows}

Many authors report a high faunal diversity of extensively used meadows (Ausden and Treweek, 1995; Bornhold, 1991), but most studies refer to meadows of a very moderate cultivation, e.g. only one cut per year. Two or more cuts per year immediately lead to a reduction of arthropod diversity (von Nordheim, 1992; Plantureux et al., 2005). The sites included in our study were mown two or three times a year, and the arthropod

APPLIED ECOLOGY AND ENVIRONMENTAL RESEARCH 8(2): 87-100. http://www.ecology.uni-corvinus.hu • ISSN 15891623 (Print) • ISSN 17850037 (Online) (c) 2010, ALÖKI Kft., Budapest, Hungary 
species numbers ranked between fallow land and pastures, whereas the diversity was on average lower than in these habitats. The numbers of individuals were comparatively high, especially in case of medium sized arthropods. However, large arthropods occurred less frequent than in pastures. Probably this was the result of the first cut, which greatly reduces the juvenile stages e.g. of Caelifera and Ensifera (Manhart et al., 2004). Therefore, these groups make an appearance mainly as medium sized individuals prior to mowing. Similarly, the number of spiders is reduced by mowing in the long term. However, due to the high number of inflorescences, especially flower visiting insects are favoured by this habitat (Sjödin, 2007; Sjödin et al., 2008) if the mowing regime is adjusted to their requirements: mowing of neighbouring areas at different times.

\section{Pastures}

Intensively used pastures show a poor arthropod diversity and in case of large arthropod species, the density is also low (v. Nordheim, 1992; Kruess and Tscharntke, 2002a,b; Radlmair and. Dolek, 2002). In case of ration grazing, the high grazing intensity in a short time has similar effects on arthropods as a cut. However, even in heavily grazed grassland dung beetles may represent a considerable amount of food for insectivores (Zahn and Hirschberger, 2001). This resource can be exploited e.g. by birds and bats which are able to forage in extended open areas without cover.

The extensively grazed pastures included in our study harboured the most diverse arthropod fauna of all habitats under cultivation, and the most species of all habitats. In respect of large arthropods, even the highest numbers of individuals within the compared types of grasslands were reached. Especially in autumn (October) pastures offered the best food supply for predators of large arthropods. Extensively used meadows harboured more large individuals on average only in early summer, probably because prior to the first cut the vegetation growth was less disturbed, compared to grazed pastures where the livestock roamed. Additionally the layer of inflorescences was much denser in extensively used meadows than in pastures until the first cut, which favours flower visiting insects (Sjödin, 2007a,b). After the first cut, the studied all-year grazed pastures (without additional mowing!) gained advantage because grazing with low intensities causes less disturbance of the vegetation than cutting, including the inflorescences layer.

Species number and diversity of arthropods are strongly influenced by the type of grazing (all-year grazing, rotation pasture), livestock species, and density and intensity of pasture care. A high grazing pressure may cause considerable damage for the fauna (Dennis et al., 1997; Gibson et al., 1992; Plantureux et al., 2005). A habitat mosaic, which is often a result of low density all-year grazing or pastoralism, is regarded as a key factor for a high diversity of the fauna (Ausden and Treweek, 1995; Riecken et al., 1998; Sjödin et al., 2008; Vulliamy et al., 2006).

Contrary to meadows the spatial structure of the vegetation in areas of low density all-year grazing shows few variations: The extent and the distribution patterns of short lawn-like sites on the one hand, and of taller vegetation on the other hand, fluctuate only gradually over the years (Zahn et al., 2003). This causes fairly constant and predictable conditions for animals and their needs in respect of foraging, shelter, reproduction or hibernation (Zahn et al., 2007b). Moreover, the mosaic structure of the vegetation 
allows the occurrence of animals that differ considerably in respect of their habitat requirements (Nyffeler, 1998; Plantureux et al., 2005).

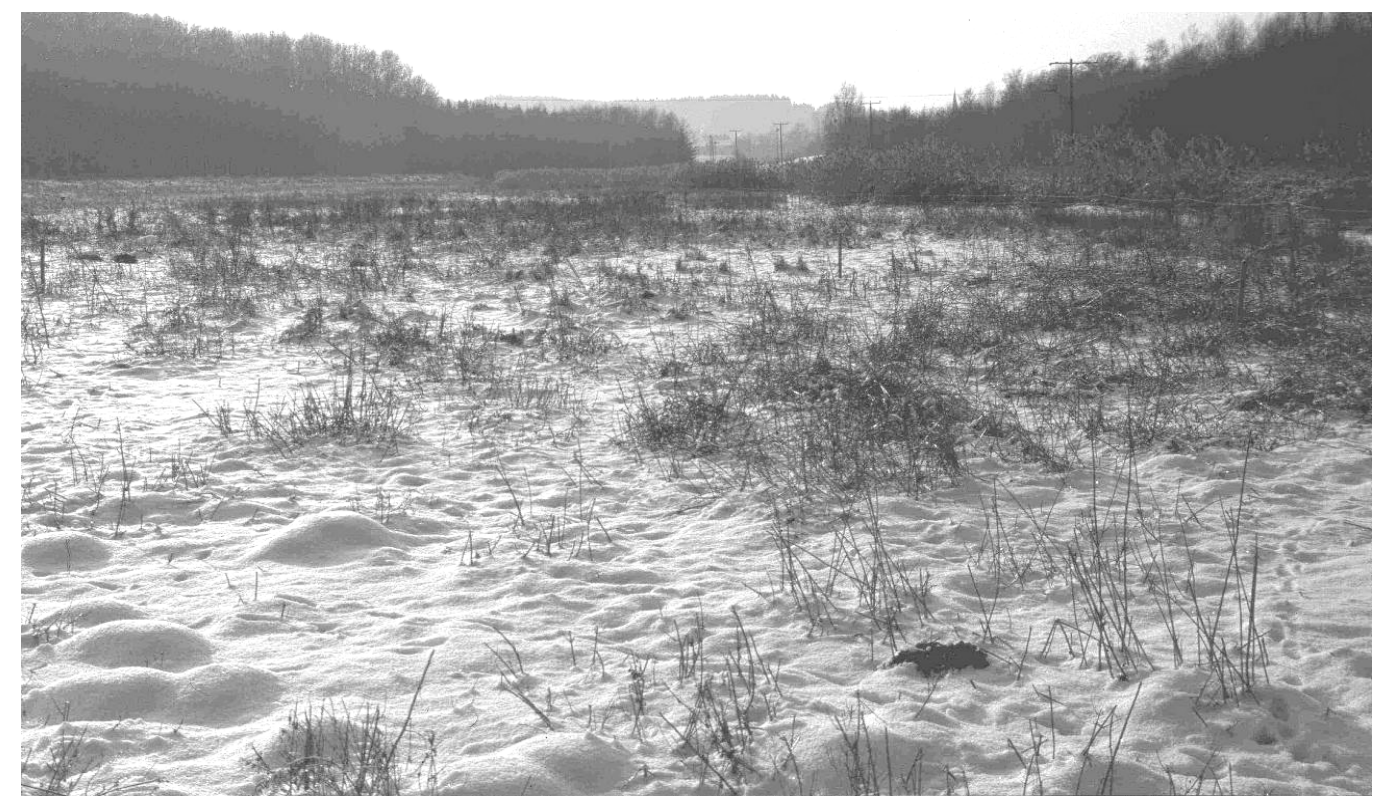

Figure 6. All-year grazed pasture in Jettenbach. The remaining patches of taller vegetation are important microhabitats for arthropods in autumn and winter

\section{Recommendation for habitat management}

None of the studied habitat types offered plenty of food all the time, a fact that supports the importance of differences in grassland usage on a local scale, if the arthropod abundance and therefore the food supply for insectivores should be optimised (Söderström, 2001; Wetterstein and Schmid, 1999). Noteworthy the abundance of arthropods, especially of larger individuals, was on average higher in pastures and extensively used meadows than in fallow land and intensively used meadows.

In spite of the fact that our study included only a part of the arthropod fauna (ground dwelling species were excluded), some general differences between the habitat types can be derived:

In grassland on soils of medium or high nutrient levels, the arthropod diversity and abundance (and therefore the food supply for insectivores) is the best in case of low intensity grazing or mowing all over the year. On fallow land of such soil types (with or without mulching), the arthropod availability is lower than in grasslands of extensive usage.

In all-year grazed pastures without additional mowing the left over patches of taller vegetation (Fig. 6) are important microhabitats for arthropods in autumn and winter (Hänsel and Plachter, 2004; Zahn et al., 2007b; Plantureux et al., 2005), which are missing on meadows. Large arthropods like grasshoppers survive even the first frosty nights in these shelters (Ingrisch and Köhler, 1998). Especially groups such as orbweavers or bush-crickets, which are greatly reduced by mowing (Manhart et al., 2004), are favoured by the habitat mosaic of areas with low grazing intensity. The patchy structure of intensively grazed lawn-like sites next to left over taller vegetation created by the livestock is therefore of high value from the viewpoint of arthropod conservation 
(Atkinson et al., 2004; Perkins et al., 2000; McCracken and Tallowin, 2004). Additional mowing, which is suggested by agricultural experts (Elsässer 2000), should be avoided.

In case of ration grazing or meadows, where such a habitat mosaic does not exist, stripes of fallow or rarely mown grassland along the edges can have a comparable function for arthropods and may therefore favour the diversity and richness of species.

Acknowledgements. We are particularly grateful to Hans Drobny, who kindly read the manuscript. Inge Steidl helped to investigate the plant species richness. This study was financed by the Bavarian Fond for Nature Conservation (Bayerischer Naturschutzfonds).

\section{REFERENCES}

[1] Atkinson, P.W., Buckíngham, D., Morris, A.J. (2004): What factors determine where invertebrate-feeding birds forage in dry agricultural grasslands. - Ibis 146: 99-107.

[2] Atkinson, P.W., Fuller, R.J., Vickery, J.A., Conway, G.J., Tallowins, J.R., Smith, R.E., Hayson, K.A., Ings, T.C., Brown, V.K. (2005): Influence of agricultural management, sward structure and food resources on grassland field use by birds in lowland England. Journal of Applied Ecology 42(5): 932-942.

[3] Ausden, M., Treweek. J. (1995): Graslands. - In: Sutherland, W.J., Hill, D.A. (eds): Managing habitats for conservation. Cambridge University Press. Cambridge, pp 197229.

[4] Bährmann. R., Müller, H.J. (1995): Bestimmung wirbelloser Tiere. - Spektrum Akademischer Verlag, Heidelberg.

[5] Balmer, O., Erhardt, A. (2000): Consequences of succession on extensively grazed grasslands for Central European Butterfly Communities. Rethinking conservation practices. - Conservation biology 14(33): 746-757.

[6] Barnett, P.R., Whittingham, M.J., Bradbury, R.B., Wilson, J.D. (2004): Use of unimproved and improved lowland grassland by wintering birds in the UK: - Agriculture, Ecosystems \& Environment 102(1): 49-60.

[7] Benton, T.G.; Vickery, J.A.; Wilson, J.D. (2003): Farmland biodiversity: is habitat heterogeneity the key? - Trends in Ecology and Evolution 18(4): 182-188.

[8] Blab, J. (1986): Grundlagen des Bioptopschutzes für Tiere. - Schriftenreihe für Landschaftspflege und Naturschutz 24. Kilda Verlag, Greven.

[9] Blake, S., Foster, G.N., Eyre, M.D., Luff, L. (1994): Effects of habitat type and grassland management practices on the body size distribution of carabid beetles. - Pedobiologia 38: 502-512.

[10] Bornhold, G. (1991): Auswirkungen der Pflegemaßnahmen Mahd, Mulchen, Beweidung und Gehölzrückschnitt auf die Insektenordnungen Orthoptera, Heteroptera, Auchenorrhyncha und Coleoptera der Halbtrockenrasen im Raum Schlüchtern. Marburger Entomologische Publikationen 2: 1-330.

[11] Carvell, C. (2002): Habitat use and conservation of bumblebees (Bombus spp.) under different grassland management regimes. - Biological Conservation 103(1): 33-49.

[12] Dennis, P., Young, M.R., Howard, C.L., Gordon. I.J. (1997): The response of epigeal beetles (Col.: Carabidae, Staphylinidae): to varied grazing regimes on upland Nardus stricta grasslands. - Journal of Applied Ecology 34: 433-443.

[13] Dewenter, S.I., Tscharntke, T. (2001): Succession of bee communities on fallows. Ecography 24: 83-93.

[14] Elligsen, H., Beinlich, B., Plachter, H. (1997): Effects of large-scale cattle grazing on populations of Coenonympha glycerion and Lasiommata megera (Lepidoptera: Satyridae). - Journal of Insect Conservation 1: 13-23.

APPLIED ECOLOGY AND ENVIRONMENTAL RESEARCH 8(2): 87-100 http://www.ecology.uni-corvinus.hu • ISSN 15891623 (Print) • ISSN 17850037 (Online) (c) 2010, ALÖKI Kft., Budapest, Hungary 
[15] Elsäßer, M. (2000): Wirkungen extensiver und intensiver Weidenutzungsformen auf die Entwicklung und Verwertbarkeit von Grünlandaufwüchsen. - Natur und Landschaft 75: 357-363.

[16] Fricke, M., Nordheim, H. (1992): Auswirkungen unterschiedlicher Bewirtschaftungsweisen des Grünlandes auf Heuschrecken in der Oker-Aue (Niedersachsen). - Braunschweiger naturkdl. Schriften 4: 59-89.

[17] Gibson, C.W.D., Hambler, C., Brown, V.K. (1992): Changes in spider (Araneae): assemblages in relation to succession and grazing management. - Journal of Applied Ecology 29: 132-142.

[18] Güttinger, R. (1997): Jagdhabitate des Großen Mausohrs (Myotis myotis): in der modernen Kulturlandschaft. - Buwal-Schriftenreihe Umwelt 288.

[19] Hänsel, N., Plachter, H. (2004): Auswirkung verschiedener Beweidungsformen auf die Raumstruktur ausgewählter Wirbelloser. - Schriftenreihe für Landschaftspflege und Naturschutz 78: 261-271.

[20] Ingrisch, G., Köhler, G. (1998): Die Heuschrecken Mitteleuropas. - Westarp Wissenschaften, Magdeburg.

[21] Kruess, A., Tscharntke, T. (2002a): Grazing Intensity and the diversity of Grasshoppers, Butterflies, Trap-Nesting Bees and Wasps. - Conservation Biology 16: 1570-1580.

[22] Kruess, A., Tscharntke, T. (2002b): Contrasting responses of plant and insect diversity to variation in grazing intensity. - Biological Conservation 106: 293-302.

[23] Langton, T., Burton, J.A. (1997): Amphibians and Reptiles: Conservation Management of Species and Habitats. - Council of Europe (Planning and Management Series).

[24] Lauenstein, G. (1986): Tipuliden als Grünlandschädlinge. - Zeitschrift für angewandte Zoologie 73: 385-431.

[25] Manhart, C., Marschalek, H., Karg, J. (2004): Renaturierung feucht-nassen Grünlands im Voralpenraum. Untersuchungen zur Vegetationsentwicklung sowie zur Biomasse und Diversität bei Insekten. - Natur und Landschaft 79(6): 257-263.

[26] McCracken, D.I., Tallowin, J.R. (2004): Swards and structure: the interactions between farming practices and bird food resources in lowland grassland. - Ibis 146: 108-114.

[27] Nordheim, H. (1992): Auswirkungen unterschiedlicher Bewirtschaftungsmethoden auf die Wirbellosenfauna des Dauergrünlandes. - NNA-Berichte 4(92): 13-26.

[28] Nyffeler, M. (1998): Stress im grünen Gras. Einfluss der Bewirtschaftung auf Wiesenspinnen. - Ornis 5: 4-9.

[29] Perkins, A.J.; Whittingham, M.J., Bradbury, R.B., Wilson, J.D., Morris A.J., Barnett, P.R. (2000): Habitat characteristics affecting use of lowland agricultural grassland by birds in winter. - Biological Conservation 95(3): 279-294.

[30] Perner, J., Wytrykush, C., Kahmen, A., Buchmann, N., Egerer, I., Creutzburg, S., Odat, N., Audorff, V., Weisser, W. (2005): Effects of plant diversity, plant productivity and habitat parameters on arthropod abundance in montane European grasslands. - Ecography 28: 1-14.

[31] Plantureux, S., Peeters, A., McCracken, D. (2005): Biodiversity in intensive grasslands: Effect of management, improvement and challenges. - Agronomy Research 3: 153-164.

[32] Radlmair, S., Dolek, M. (2002): Auswirkung der Beweidung auf die Insektenfauna von Feuchtgrünland unter besonderer Berücksichtigung von Tagfaltern und Heuschrecken. Laufener Seminarbeiträge 1/02: 23-34.

[33] Riecken, U., Finck, P., Klein, M., Schröder, E. (1998): Überlegungen zu alternativen Konzepten des Naturschutzes für den Erhalt und die Entwicklung von Offenlandbiotopen. - Natur und Landschaft 73: 261-270.

[34] Rudolph, B.U. (2004): Gefährdung und Schutz. - In Meschede, A., Rudolph, B.U. (eds): Fledermäuse in Bayern. Ulmer-Verlag. Stuttgart: 356-383.

[35] Sjödin, N.E., Bengtsson, J.; Ekbom, B. (2008): The influence of grazing intensity and landscape composition on the diversity and abundance of flower-visiting insects. Journal of Applied Ecology 45(3): 763-772.

APPLIED ECOLOGY AND ENVIRONMENTAL RESEARCH 8(2): 87-100. http://www.ecology.uni-corvinus.hu • ISSN 15891623 (Print) • ISSN 17850037 (Online) (c) 2010, ALÖKI Kft., Budapest, Hungary 
[36] Sjödin, N.E. (2007a): Pollinator diversity and grazing intensity in the landscape. Biodiversity and Conservation 16: 2103-2121.

[37] Sjödin, N.E. (2007b): Pollinator behavioural responses to grazing intensity. Biodiversity and Conservation 16: 2103-2121.

[38] Söderström, B., Svensson, B., Vessby, K., Glimskär, A. (2001): Plants, insects and birds in semi-natural pastures in relation to local habitat and landscape factors. - Biodiversity and Conservation 10: 1839-1863.

[39] Söderström, B., Pärt, T., Linnarsson, E. (2001): Grazing effects on between-year variation of farmland bird communities. - Ecological Applications 11(4): 1141-1150.

[40] Tietze, F. (1985): Veränderungen der Arten- und Dominanzstruktur in Laufkäfertaxozönosen (Coleoptera - Carabidae): bewirtschafteter Graslandökosysteme durch Intensivierungsfaktoren. - Zool. Jb. Syst. 112: 367-382.

[41] Tscharntke, T.; Steffan-Dewenter, I.; Kruess, A., Thies, C. (2002): Characteristics of insect communities on habitat fragments: a mini review. - Ecological Research 17: 229239.

[42] Vickery, A., Tallowin, J.R., Feber, R.E., Asteraki, E.J., Atkinson, P.W., Fuller, R.J., Brown, V.K. (2001): The Management of Lowland Neutral Grasslands in Britain: Effects of Agricultural Practices on Birds and Their Food Resources. - Journal of Applied Ecology 38(3): 647-664.

[43] Vulliamy, B., Potts, S.G., Willmer, P.G. (2006): The effects of cattle grazing on plantpollinator communities in a fragmented Mediterranean landscape. - Oikos 114: 529-543.

[44] Wetterstein, W., Schmid, B. (1999): Conservation of Arthropod Diversity in Montane Wetlands: Effect of Altitude, Habitat Quality and Habitat Fragmentation on Butterflies and Grasshoppers. - Journal of Applied Ecology 36(3): 363-373.

[45] Wingerden, W., Kreveld, A., Bongers, W. (1992): Analyses of species composition and abundance of grasshoppers in natural and fertilized grasslands. - J. Appl. Ent. 113: 138152.

[46] Zahn, A., Hirschberger, P. (2001): Die Dungkäferfauna von Rinder-Standweiden in Oberbayern. - Zeitschrift für Ökologie und Naturschutz 9: 219-224.

[47] Zahn, A., Juen, A., Traugott, M., Lang, A. (2007b): Low density cattle grazing enhances arthropod diversity of abandoned wetland. - Applied Ecology and Environmental Research 5: 73-86.

[48] Zahn, A., Meinl, M., Niedermeier, U. (2003): Auswirkungen extensiver Rinderbeweidung auf die Vegetation einer Feuchtbrache. - Naturschutz und Landschaftsplanung 35(6): 171-178.

[49] Zahn, A., Rodrigues, L., Rainho, A., Palmeirim, J. (2007): Critical times of the year for Myotis myotis, a temperate zone bat: roles of climate and food resources. - Acta Chiropterologica 9(1): 115-125. 